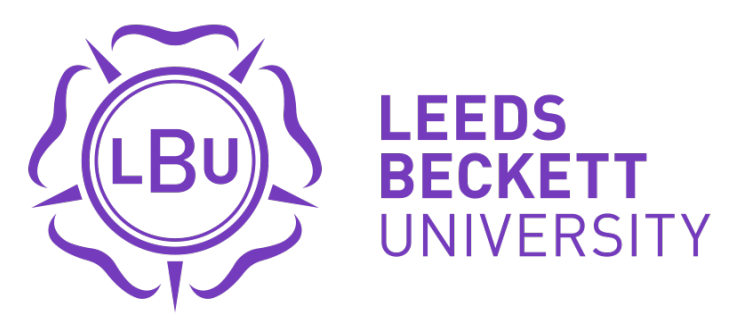

Citation:

Morgan, J (2015) Piketty's Calibration Economics: Inequality and the Dissolution of Solutions? Globalizations, 12 (5). 803 - 823. ISSN 1474-7731 DOI: https://doi.org/10.1080/14747731.2015.1072950

Link to Leeds Beckett Repository record:

https://eprints.leedsbeckett.ac.uk/id/eprint/2122/

Document Version:

Article (Accepted Version)

The aim of the Leeds Beckett Repository is to provide open access to our research, as required by funder policies and permitted by publishers and copyright law.

The Leeds Beckett repository holds a wide range of publications, each of which has been checked for copyright and the relevant embargo period has been applied by the Research Services team.

We operate on a standard take-down policy. If you are the author or publisher of an output and you would like it removed from the repository, please contact us and we will investigate on a case-by-case basis.

Each thesis in the repository has been cleared where necessary by the author for third party copyright. If you would like a thesis to be removed from the repository or believe there is an issue with copyright, please contact us on openaccess@leedsbeckett.ac.uk and we will investigate on a case-by-case basis. 


\section{Piketty's calibration economics: inequality and the dissolution of solutions?}

Jamie Morgan, Leeds Beckett University

Abstract: By popularising interest in inequality Thomas Piketty's Capital in the Twenty-First Century has made a significant contribution. It has helped to change the basic terms of debate regarding wealth and income. However, Capital exhibits several weaknesses. The overall statement of Piketty's 3 laws tends to confuse the reader by conflating capital with all forms of wealth, and capital with the current market valuation of wealth assets. The whole creates a form of empiricism by metrics or calibration. The aggregation also lends itself to data as history rather than historically grounded explanation of evidence. Concomitantly, it lacks a theorisation of capitalism, of power, of the state, of social movements and social transformations. This affects the way in which possible solutions to inequality are directed, creating an inherent conservativism. However, it does provoke further grounds for ethical counterargument productive of more progressive solutions to the problems it highlights.

Keywords: Piketty, capital, inequality

\section{Introduction}

In the neoliberal age we have naturalised the rich. However, the success of Thomas Piketty's Capital in the Twenty-First Century has done a great deal to legitimate a rather differently inflected concern. It is now permissible to ask: can we, should we, afford the rich?

Growing income and wealth inequality have gradually become areas of public concern but this concern has become more acute, and more politically febrile, in the wake of the global financial crisis. The election victory by Syriza in Greece, and the Occupy Movement speak directly to this. Austerity responses to the crisis have distributed the fallout costs to the many from the few who benefitted most from the preceding decades. Meanwhile, central bank policy responses have created new opportunities for the global rich to become even richer. ${ }^{i}$ To a large degree the idea that the rest of us are dragged along in the wake of the wealthy has been exposed as a myth. Returns captured (rather than created) by the rich have affected the many, and not just in a financial sense. The associated fiscal and policy effects on welfare, health systems, pensions, collective union activity and our simple sense of community cohesion and quality of life, rather than quantity and materiality, have all been harmed. And this is just in the Global North. For the Global South second best "development" forms have fuelled the North in many ways, creating the underlying deflationary effects that have kept the North consuming as well as contributing to the current account imbalances that lead to capital flows for asset bubbles. In return the Global South has experienced its own problems as its nation's reproduce the same socio-economic cleavages as the North. In 2014 Forbes identified 2,325 billionaires, an increase of more than 10\% on 2013 and 190 of these were in China. 
Inequality now matters more to political and economic elites and the ordinary citizen, albeit from different ends of the same reasoning focused on the economics of political stability - protection of the right to what is "mine" within the status quo versus a deep sense of injustice. A great deal has now been written regarding Piketty's work (see Fullbrook \& Morgan eds. 2014). It is widely acknowledged to be the well-intentioned product of an engaged and highly reasonable social democrat; one unfairly demonised at various times as a data manipulating unreconstructed Marxist - in places where such an appellation is a pejorative term. ${ }^{\text {ii }}$

The key questions arising from Capital are: Can it galvanise opinion in an appropriate way or will it become more of a hindrance than a help in understanding contemporary capitalism, and in constructing alternatives? Yanis Varoufakis, Greece's short-tenured finance minister, certainly thinks it will prove a hindrance (Varoufakis, 2014). In many respects one might argue that Capital has become successful precisely because of its flaws. It is, as Robert Wade has noted, "reassuringly conventional in its analysis and prescriptions, and so less threatening to familiar ways of thought," (Wade, 2014: p. 11). It is radical, but principally in the conservative context of mainstream economics. Beyond that context one might describe it as a palatable form of radicalism whose constructions, concessions, and omissions undermine its capacity to carry the weight of expectation placed upon it.

\section{Capital in brief}

\section{The Core Argument}

Piketty's core claim is that there is a basic tendency in capitalism for stocks of wealth (assets) and flows of income (both from assets and work) to become concentrated. Capitalism has no inherent mechanisms that serve to prevent this. Economies do not automatically self-equilibrate in ways that lead also to more equal distributions of wealth and income. Economic growth and development do not lead necessarily to Kuznet effects, where over time wealth and income become more evenly distributed within nations.iii It is only through two situations that the basic tendency towards inequality can be, and has in the past, been offset. First, by wars and severe economic disasters. These can wipe out existing concentrations of wealth and also affect the immediate capacity to earn significant income based on the current ownership and/or control of assets. Here, events can serve to reset actual wealth and income. Such events also create pressures for institutional arrangements, and these provide a second way in which restrictions can be placed on the potential to accumulate wealth and to earn unequal income. Rules and regulations (welfare states, progressive taxation and redistributive systems etc.) combine with socialised restraints or customs (cultures that limit the claims on income and assets of elites who have positional power that could be exploited for greater gain). It is inherent to Piketty's argument that these two situations, war and reactive institutional arrangements, are temporary and non-necessary. The long-term unconstrained tendency is towards concentrations and inequality. 
Piketty notes that "Intellectual and political debate about the distribution of wealth has long been based on an abundance of prejudice and a paucity of fact [... and there is therefore] a role for research that is at least systematic and methodical, if not fully scientific" (Piketty, 2014: p. 3). His argument is presented as emerging from an empirical form of historical analysis. He produces important data but the question then arises, to what degree has he explained the past and outlined the reasons why a given future may unfold? What makes a fact a fact worth knowing in a particular way? Here, the initial concepts matter.

The historical analysis is primarily focused on tracking "the respective shares of global income going to labor and capital and on how those shares have changed since the eighteenth century" (Piketty, 2014: p. 39). Piketty's purpose is "not to plead the case of workers against owners but rather to gain as clear as possible a view of reality" (Piketty, 2014: p. 40). He identifies a key role for "the historical evolution of the capital/income ratio" (see below, Piketty, 2014: p. viii). He states that he will "use the words capital and wealth interchangeably, as if they were perfectly synonymous," (Piketty, 2014: p. 47), and then defines capital as, "the sum total of nonhuman assets that can be owned and exchanged on some market. Capital includes all forms of real property (including residential real estate) as well as financial and professional capital (plant, infrastructure, machinery, patents and so on) used by firms and government agencies" (Piketty, 2014: p. 46). The important point here is the inclusion of financial assets and that these can be of any form and owned by anyone.

Piketty's investigation requires data on shares of national income and accumulated values of owned assets. He collectively refers to the latter as national capital defined as "the total market value of everything owned by the residents and governments of a given country at a given point in time, provided that it can be traded on some market," (Piketty, 2014: p. 48; emphasis added - this becomes important later, national capital is expressed as a percentage of annual national income, for example, 400\%).

The availability of the relevant data for Piketty's inquiry requires a nation to have some interest in collection. As he notes, reliable data on annual income tends to follow from the implementation of an income tax, data on wealth tends to be available for earlier periods based on a broader range of sources (aggregations from valuations for inheritance, estate taxes etc., but requires more ingenuity to capture). In the earliest national cases, data availability typically follows from the need to finance wars or restructure in the wake of revolution or transformation. It tends to be associated with the gradual emergence of complexly administered and bureaucratic mercantile and then industrial states, often accompanied by the work of a pioneer in political economy (Piketty, 2014: pp. 16-20, 55-9). In later cases it is based on the demands for conformity from regional and global governance organizations such as the World Bank.

Piketty's historical analysis and its "global" ambition is based on initially few cases that are assumed to be "generalisable" and then on what gradually becomes available (much of it stored in the World Top Incomes Database). His oldest and most continuous sources are Britain and France beginning from around 1700, 
followed by Germany, the United States and Sweden from around 1800, the rest of Europe and Japan from the early twentieth century, and extending to other nations of the world through the second half of the twentieth century.iv

Based on the available data Piketty identifies a significant $U$ shape in national capital for individual states and for Europe and America collectively. The total value of accumulated capital assets falls in the early to mid decades of the twentieth century and then begins to recover from World War II (see Piketty, 2014: p. 165). This is a period of war and economic calamity, which destroys capital (though less so in the United States) and resets the ownership of wealth, shifting some from the private to the public (see also Piketty, 2014: p. 147). It also leads to initial effects on the share of income so that in the period thereafter there are institutional breaks on inequality of income and (to a lesser degree) private wealth, which initially prevent a rapid rise in inequality of wealth (a concentration based on shares of the accumulation of national capital).v However:

The shocks that buffeted the economy in the period 1914-1945 - World War I, the Bolshevik Revolution of 1917, the great Depression, World War II, and the consequent advent of new regulatory and tax policies along with controls on capital - reduced capital's share of income to historically low levels in the 1950s. Very soon, however, capital began to reconstitute itself. The growth of capital's share accelerated with the victories of Margaret Thatcher in England in 1979 and Ronald Reagan in the United States in 1980, marking the beginning of a conservative revolution [...] By 2010, and despite the crisis that began in 2007-2008 capital was prospering as it had not done so since 1913. (Piketty, 2014: p. 42)

So, the post WWII prosperity phase in world economic history combined greater income equality, redistributive state policies, and regulatory restraints on capital. The Reagan/Thatcher counter revolution facilitated a historical reversal of these historical conditions, corresponding with the onset of the era of neoliberal economic globalization.

For Piketty, the mid twentieth century is an exception to the basic tendencies for wealth and income inequality to grow. This then leads to a focus on the reemergence of inequality of income and wealth. Piketty finds that the top deciles income share in the United States rises from around 33\% of total income in 1970 to more than 48\% in 2010, whilst in Europe it rises from around 30\% to 35\%, but with significant variation; for example, the UK figures are $28 \%$ to $42 \%$ whilst Sweden's are around 26\% to 28\% (Piketty, 2014: pp. 323-4). The top deciles share of total wealth increased in the United States from around 65\% in 1970 to over $70 \%$ in 2010, and in Europe from around 60\% in 1970 to around 65\% in 2010, again with significant variation between states (Piketty, 2014: p. 349). In terms of wealth share, moreover, there are also concentration augmentations as one moves to the top centile or $1 \%$ and then top $0.1 \%$. The top $1 \%$ in the United States owned almost $35 \%$ of all national wealth in 2010 . The contemporary significance of these trends for the financial crisis is made clear for the United States in particular: 
In my view there is absolutely no doubt that the increase in inequality in the United States contributed to the nation's financial instability. The reason is simple: one consequence of increasing inequality was virtual stagnation of the purchasing power of the lower and middle classes in the United States, which inevitably made it more likely that modest households would take on debt (Piketty, 2014: p. 297)

Note the underlying underconsumptionist stance here, consequent upon a secular trend to stagnating or declining real wages in significant advanced capitalist economies over the past several decades.

Piketty's point is that the top echelons of society have in recent decades been the recipients of the majority of growth in national income, with the inevitable implication that the rest of society have not been direct beneficiaries of growth. For example, the "bottom 90\%" in the United States saw income growth of $0.5 \%$ per year 1977-2007, whilst the top 1\% took a total of $60 \%$ of growth in national income (Piketty, 2014: p. 294). As Piketty notes, "It is hard to imagine an economy and society that can continue functioning indefinitely with such extreme divergence between social groups," (Piketty, 2014: p. 297). Moreover, this has continued since the financial crisis. For example, the top 1\% were recipients of more than $90 \%$ of the increase in national income 2009-2012 in the United States. So, the recent global economic crisis has not (unlike in the twentieth century) served to reset income and wealth potentials along more egalitarian lines. One might note here Eichengreen's contrast between the Great Depression and the Great Recession (2015). He suggests that the character of the initial crisis response to the latter rendered a more dramatic set of transformations in the institutions and structure of the global capitalist economic system less possible, while potentially thereby sewing the seeds of future systemic crisis.

Piketty's analysis of his data is far more detailed than can be set out here. ${ }^{\text {vi }} \mathrm{He}$ covers France, Britain and the United States at great length and then the aggregates for Europe and some extension to the rest of the world (for example, Piketty, 2014: pp. 460-3). The work is 577 pages plus notes. So the figures stated serve merely to illustrate the general form of his findings. vii His underlying point is that the data seems to express a return to the trends prior to his period of exception in the early-to-mid twentieth century. However, his analysis also makes clear that a return is not a rerun. There are significant differences. Wealth concentrations were different in the eighteenth and nineteenth centuries because societies contained different mixes of potential assets based on the way economies were structured. Agricultural land dominated and then later commercial and industrial enterprises emerged and the joint stock company was eventually created. The period prior to the twentieth was also one of insignificant inflation (Piketty, 2014:pp. 102-9). A social elite could rely on returns to their assets (since nominal and real were the same), and inheritance meant wealth was readily transmitted. A class of rentiers dominated a highly unequal society - an idle rich. However, today's rich include, and this is most developed in the United States, also the working rich - the "supermanagers" or executives who effectively control their own compensation culture (Piketty, 2014: pp. 264-5, 277-8). Inheritance still matters more than the public might think and the rise of 
supermanagers has not been a product of a more socially mobile and in this sense meritocratic society, since the majority do not become more mobile because a tiny fraction achieve success (Piketty, 2014: pp. 378, 417, 424).

Underlying difference is a basic enduring relation, as the scale of wealth increases the returns that can be commanded based on the scale of that wealth also increase. So the returns to the wealthy are not just bigger because of scale, they are bigger because scale creates effects on the ability to earn more per unit of wealth. This is the same for both the modern idle rich and the working rich, though not necessarily always for the same reasons. Great wealth creates access to more lucrative investment opportunities (insider information, better investment management based on the rules of systems and how they can be exploited etc), and so annual income can be greater for the idle rich. Since, the working rich also control huge assets they can structure their own compensation to extract significant proportions of the income earned by those assets (via stock options, tax privileges etc). In both cases the net effect is that wealth creates more wealth through capturing more of the income created in the economy. Hence the effects Piketty identifies - relative gains to the top $10 \% 1 \%$ and $0.1 \%$ at the expense of the rest. Piketty describes this as the return to "patrimonial capitalism" - a society dominated by concentrations of private wealth - albeit one that now has, as a residue of the twentieth century transformations that once benefitted the many, a minority owning (in a national capital sense) patrimonial middle class (Piketty, 2014: p. 173, 237, 260-1).

\section{The 3 laws viii}

Intuitively Piketty's data suggests that there is an internal set of mechanisms that render societies steadily more unequal. This brings us to Piketty's 3 "laws". The headline claims are clearly summarised pp. 20-27. The first chapter contains the initial reference to his 3 laws, and states the first. ${ }^{i x}$ One should note here that Piketty is intermittently critical of some of the characteristics of modern economics:

To put it bluntly, the discipline of economics has yet to get over its childish passion for mathematics and for purely theoretical and often highly ideological speculation, at the expense of historical research and collaboration with the other social sciences. Economists are all too often preoccupied with petty mathematical problems of interest only to themselves. This obsession with mathematics is an easy way of acquiring the appearance of scientificity without having to answer the far more complex questions posed by the world we live in. (Piketty, 2014: p. 32)

His statement omits several of the reasons why economists express their ideas in mathematical form. ${ }^{\mathrm{x}}$ It carries intellectual capital to do so, it is simply expected, it is part of being taken seriously as an economist, and it enables one to add a degree of authority in the form of conditional certainty to one's claims on both the past and future. It gives a sense of order and "theory" to what would otherwise just be metrics, albeit important ones. Data becomes not just what happens, but a pattern that can be discerned and then an actual expressible tendency. However, the 
mathematical form is not the data, it is a way of expressing the relations one thinks one finds in the data in a convenient symbolic shorthand. Without the shorthand these are often things one could simply state in ordinary language terms based on the raw data - when $\mathrm{x}$ does one thing $\mathrm{y}$ will often do another. Ordinary language tends to lead to the requirement to add a "because" to the statement. However, once rendered in symbolic form it can appear as though something has been explained even though "because" may be omitted or severely attenuated, particularly where a quantity relation is simply stated. It need not be an explanation, it involves no necessary whys, it can be just a way of translating a claim from words to symbols. This is essentially what Piketty's first two laws are and this affects his third law. This matters because it creates a tension in terms of the statement "an easy way of acquiring the appearance of scientificity without having to answer the far more complex questions posed by the world we live in." It is important to highlight that the general gravitas that mathematics provides in a social science context can conceal the limits of any given mathematical expression, and obfuscate regarding the lack of adequate further explanation.

Piketty has a very loose sense of what a law is. He refers to his throughout as "fundamental laws of capitalism" and sometimes links the phrasing with reference to the "deep structures of capitalism" implying that the former, in the absence of further elaboration, arise out of the latter. However, as he clearly acknowledges his first law is simply an identity, a first move in creating a definition that can then be used to subsequently express his main claim about growing inequality in the following laws. Piketty is interested in exploring shares of national income, specifically the increasing share flowing to what he defines as capital, which then can be used to establish how wealth accumulates. Accordingly he needs first to define capital's share of national income, for which he uses the symbol $\alpha$. So the first law is (Piketty, 2014: p. 52):

$$
\alpha=r \times \beta
$$

*Capitals share of national income equals the rate of return on capital multiplied by the capital /income ratio

$r$ is the rate of return on capital. This is the \% return to the owner of an asset. $\beta$ is the capital/income ratio. This simply means the total stock of capital expressed in terms of the amount of income generated in a given period. It is the historical accumulation of the value of assets (all wealth) in terms of the value of the current annual period of income generation. The historic accumulation is all the wealth that can receive the rate of return. The more of it there is as a proportion of current income generation then the more of that income will flow to capital. So a higher rate of return and/or a higher accumulation of historic capital on which returns can be earned eats up more of the share of current income generation. As such the first law just states capital's share is created by the rate of return and by the relative size of accumulated capital. As both of these rise so capital's share must rise.

Piketty then asks how one might state the potential for the capital income ratio to increase. How does one express a simple mechanism by which national income translates into more or less accumulating capital? Here, Piketty assumes that if an 
economy is saving more rather than consuming then more of its income is going to create capital assets (based on his definition of capital). So as the savings rate as a \% of national income increases then capital will accumulate and there will be more capital to earn the rate of return and so more of income over time will be capital's share (in the first law). However, if the economy is growing then the savings, which create more capital, are progressively part of an ever larger economy and so the rate of increase of capital's share as a proportion of the economy may be lower. This leads to Piketty's second law, which simply states that the capital/income ratio is dependent on the rate of saving compared to the rate of growth of the economy. A faster growing economy does not accumulate capital (measured proportionately rather than in simple absolute levels) as quickly for any given saving rate (remembering savings represent capital). He states this as (Piketty, 2014: p. 166)

$$
\beta=s / g
$$

The capital/income ratio equals the annual savings rate divided by the rate of growth of national income

$\beta$ again means the capital/income ratio, $s$ means the annual saving rate expressed as a \%, and $g$ the rate of growth of national income. Piketty notes that the significance of the effects of $s / g$ ought to be assessed in the long term, smoothing out any volatility over many years to identify the basic trend effect on $\beta$. The assumption is that over time the savings rate compared to the growth rate provides a way to express the dynamics of how capital accumulates in comparison to national income and so $s / g$ converges on $\beta$ (e.g. if $\mathrm{s} / \mathrm{g}$ is 6 for long enough then $\beta$ will be $600 \%$ ).

So far we have two simple statements of relations. The first implies that as the rate of return increases and/or the relative size of accumulated capital increases then capital's share of national income will increase. The second implies that since savings create capital, then the higher the savings rate as a \% of national income, the faster capital will accumulate, but that this is offset by faster economic growth, which slows down the relative growth of accumulated capital compared to national income. Lower growth, therefore, implies a more rapid potential for the relative accumulation of capital and, as a consequence an increase in capital's share of national income in the first law.

The simple mechanics of how different components of Piketty's first two laws interact lead to his third law. The first two laws imply that capital's share of national income is likely to rise because capital will accumulate relative to national income. It then matters who owns that capital, since it is the owners of capital who will receive the growing share of national income. The vast majority of Piketty's work, is concerned with establishing that capital is in the main held privately, is influenced by inheritance and is also concentrated in few hands. So, the laws then become a way to state that as capital accumulates and its share of national income rise it is those who own more that will benefit more and their very ownership will over time augment their wealth. Moreover, given the distribution of ownership and also (of income from work) then inequality will simply continue to accumulate 
into the future, particularly if the rate of return on capital does not fall as capital accumulates, and if the rate of return exceeds the rate of economic growth, since this will likely lead to more rapid growth in capital's share based on the first law and with less offsetting in the second law. So, over time more and more of national income will be eaten up by returns to capital and more and more of that capital will be concentrated in fewer hands. Piketty states this third law as a "fundamental inequality," acknowledging that it is a "contingent historical proposition, which is true in some periods and political contexts and not in others," (Piketty, 2014: pp. $25,358)$ :

$$
r>\mathrm{g}
$$

where $r$ is the rate of return earned by capital and $g$ is the growth of national income. ${ }^{x i}$ For Piketty, this mathematical inequality is a "fundamental force for divergence" (Piketty, 2014: p. 424). For it to be so then one needs to either assume or establish that the rate of return to capital is relatively constant (rather than falling) and that the long-term state of growth is low. Piketty does this on a global basis and he uses this to connect the past and future.

Note: these patterns of accentuated tendency to concentration of capital are discernible in many countries over the period of neoliberal economic globalization, and contribute to a global tendency towards increasing oligarchization of wealth. The contingent historical conditions that have facilitated such concentration include weakened regulatory regimes on capital, weakened redistributive policies, weakened labour rights, and weakened or lax tax regimes that enable systematic tax avoidance by high net worth individuals and corporations.

Piketty makes the point that the long-term rate of global growth, rather than individual national growth, has always been relatively low in \% terms. Moreover, whilst there has been a step-change increase in growth after the industrial revolution, and this has extended because of the spread of industrialisation and trade through the catch-up of developing nations, one cannot augment global growth forever through dissemination effects. If one looks also to the underlying technological basis of change then growth in total may be higher after the industrial revolution but it is much lower than one might expect in toto (achieving its highest rate of $2.5 \%$ in the period $1950-1980$, but tending to be around $1 \%$ less than this). xii Piketty then uses this as context for $r>$ g. Growth seems to be constrained and one can project this forward. There is, however, no similar limit on the claim of capital assets to a rate of return (Piketty, 2014: pp. 353, 360; however, see later).xiii

Piketty then takes it that one can work on the basis of say $r$ of 4-5\% (scaled for the privileged) and long term g tending towards 1 to $1.5 \%$, but with variation based on catch-up (Piketty 2014: pp. 95-102, 563). He then assumes that if there is "no significant political reaction that will alter the course of capitalism and financial globalization", and no radical technological breakthrough transforming growth, then there is no reason to expect any change in $r>$ g over the next century, and perhaps even "the next two centuries" (Piketty, 2014: pp. 353-358). Capital will continue to accumulate and concentrate (perhaps even "indefinitely", Piketty, 
2014: p. 519). This claim is made despite the statement by Pikety that current levels of inequality in the United States mean "It is hard to imagine an economy and society that can continue functioning indefinitely with such extreme divergence between social groups," (Piketty, 2014: p. 297). Clearly, the long-term political consequences of extreme inequality demands more exploration, including the probability that increasingly authoritarian capitalist states will emerge to preside over such highly unequal societies in future.

In any case, the quote is indicative that Piketty is not committing himself in a simple sense to an underlying determinism. He is rather creating context for an institutional solution to a problem that cannot simply be assumed will solve itself, i. e. the need for a deconcentration of capital. In the context of addressing mainstream economics and neoclassical ways of posing a problem his own discussion and model building is an understandable discursive move. It leads to the final part of the book where Piketty makes the case that since the problem of $r>\mathrm{g}$ appears to be universal, based on a simple expression of the mechanics of capitalism, and since the beneficiaries of it are increasingly mobile and global, then a solution must also be global, specifically a progressive global tax on capital as private wealth (perhaps achieved in steps beginning with regional agreements). The actual rate can be low since initially the tax needs to embed and its very existence creates information and starts a process of socialisation to new rules. xiv Moreover, as an annual tax rather than a sporadic levy the take will be cumulative and, for Piketty, the point is not to radically expropriate nor "to finance the social state but to regulate capitalism. The goal is first to stop the indefinite increase of inequality of wealth, and second to impose effective regulation on the financial and banking system in order to avoid crises," (Piketty, 2014: p. 518).Here Pikkety moves in conjuncture with those who advocate strengthening state authority over private financial actors and markets, seeking measures to correct past mistakes and enhance overall systemic stability in the wake of the global financial crisis (see Morgan and Sheehan, 2015). Pikkety states his goals modestly.

I was vaccinated for life against the conventional but lazy rhetoric of anticapitalism [...] I have no interest in denouncing inequality or capitalism per se - especially since social inequalities are not in themselves a problem as long as they are justified, that is, "founded only upon common utility," as article I of the 1789 Declaration of the Rights of Man and the Citizen proclaims [...] I am interested in contributing, however modestly, to the debate about the best way to organize society and the most appropriate institutions and policies to achieve a just social order. (Piketty, 2014: p. 32)

For Piketty, whatever its faults or "imperfections" Capital is a work in the construction of facts, a historical analysis seeking out data to answer an important socio-economic question. The pursuit of that data necessarily required collaboration, a creative approach to problems, and an inter-disciplinary openmindedness that many modern economists simply lack (Piketty, 2014: pp. 574-5). He places his work in the tradition of "political economy" which, "may seem rather old-fashioned but to my mind conveys the only thing that sets economics apart from the other social sciences: its political normative and moral purpose," (Piketty, 2014: p. 574). 


\section{The context of critique}

It is important in assessing the positive contribution of Piketty's book to bear in mind just who it was written for. Piketty is an economist and his core anticipated audience would likely be other economists, and principally mainstream economists. In this context the book is radical. It places an empirical question mark against standard assumptions of wealth distribution effects, it uses methods typically eschewed by mainstream economists, it takes an interest in institutions, and it doesn't assume that problems in a market system simply take care of themselves over the long term. The data produced is an invaluable resource for all researchers interested in inequality. For example, Olivier Giovannoni at the Levy Institute draws on Piketty's dataset. In a recent working paper he calculates that the labour share of the $99 \%$ in the United States has reduced by $15 \%$ since 1980 and in 2012 this amounted to a \$1.8 trillion transfer from labour to capital, reducing the US labour share to its 1920s level (Giovannoni, 2014). As Wade (2014) notes this shift in who gets what is not occurring in a failed state in some global backwater where a corrupt government and a predatory set of corporations pillage the population in some exceptional fashion. It has become the normal context of "advanced" capitalism, an advanced capitalism where we have been encouraged over recent decades to celebrate this context as the consequence of a dynamic process of rewards to wealth creators. Those who question this are accused of practicing the politics of envy and of flying in the face of economic progress.

It is in terms of addressing the ideological-economic constructions associated with the idea of wealth creators and progress that Capital seems most important. And it is in these terms that much of its appeal beyond economics seems to lie. Capital brings issues of ethics and justice to the fore. Economists typically evade these, despite that any economic decision-making involves rules for decisions and these have a context. The context is usually bracketed as a normative issue for others whilst the economist focuses on what is economically rational in ways that are often highly unrealistic, and which ignore that the rational has a rationale and is itself an ethical stance (a form of unstated utilitarianism, which is also often violated in terms of its own tests). Piketty's analysis is important because it creates a bridge to inequality as a problem of justice, the book has "moral purpose".

The implication of Piketty's work is that what is economically reasonable and thus ought to be allowable should flow from what is explicitly ethically reasoned and justified. Piketty's great contribution is his empirical findings. The gains from growth over the last thirty years have been mainly captured by the top decile and within that by the $1 \%$ and $0.1 \%$. This raises the important question: on what basis has the income from growth been captured? It has not been by work in any reasonable sense. It has been based on inheritance and ownership of financial assets that create a return, and it has been based on power - the power to command one's own income from "work" and by control over huge assets (corporations). So, Piketty's analysis allows one to argue that the returns to the wealthy have not been about returns to merit through labour, but rather as a product of the social power conferred by capital and by class position. This allows 
one to reframe the problem away from the idea that wealth flows naturally to an undifferentiated dynamic class of entrepreneurs, and society would be poorer (in all senses) if it were not for their activity. The idea that their wealth is deserved and that its accumulation is a reward, and by extension an incentive that drives the whole economic system, begins to dissolve.

It dissolves further when one considers that the top echelons have not become more productive in the last thirty years, so the increase in returns cannot be justified as a simple economic return based on scarcity of skills and the productive contribution of those skills. On the contrary, they are capturing a larger proportion of wealth in economies that are growing more slowly than they did in the period 1950-1980. To reiterate, Piketty's major contribution is the data that provides ammunition to challenge the implicit ethical stance of advanced capitalism - the conflations and obfuscations of the cult of the entrepreneur and of the confusion between wealth creation and capture. It provides the basis for an empirically grounded ethical counterargument. It opens up a space to construct an argument whose terms of reference are quite different; an argument where many of the rich are undeserving, since many of them live off the returns from (as well as some contribute to the construction of the system of) financial assets, and where some of those assets and the system of assets are part of the problem of modern capitalism's instability that harms us all. It provides a useful empirical basis for a more radical critique of parasitic accumulation of wealth and oligarchization, understood as social evils rather than virtues. Thus, the very rich become a societal burden, their wealth illegitimate, their position in society unjust, their existence as a group unnecessary, and their activities a threat to general economic stability and social justice. Such a critique is not personalised - it does not focus on a single individual or given instances of egregious conduct, but on how a group are able to act (for the Harvard/Chicago response to the $99 \%$ critique by Occupy etc, putting the position of the 1\%, see Mankiw 2013, and Kaplan and Rauh, 2013; Mankiw, 2015).xv

However, though one can reasonably state that Piketty provides data to challenge the ethical stance of modern capitalism, and Capital may in this sense have "moral purpose", the book is not a tightly argued moral case. The moral force of the work is dissipated. Andrew Sayer makes the moral case far more effectively in his recent book Why We Can't Afford the Rich, and does so partly based on Piketty's data (2014; see also Dorling, 2014). Though he is aware that an economy is also a social construct (Piketty, 2014: p. 55), he cannot quite shake the mainstream economist's sense that facts are neutral. Recall that he states his purpose is "not to plead the case of workers against owners but rather to gain as clear as possible a view of reality" (Piketty, 2014: p. 40). Consider also: "Rather than indulge in constructing a moral hierarchy of wealth, which in practice often amounts to an exercise in Western ethnocentrism, I think it is more useful to try to understand the general laws that govern the dynamics of wealth," (Piketty, 2014: p. 445). What Capital lacks, however, is a sense of explanatory force in which facts are never neutral because in the context of explanation they have consequences for future policy and conduct. 
Capital is sufficiently a work addressed to mainstream economists that it hesitates to forcefully make the moral case (if not for workers then) for the 99\% against the $1 \%$ based on the data. Concomitantly it does not draw out the implications of the existence of a $1 \%$ as a set of consequences for society in any clear sense (health, wealth, democracy, community etc.). It is rather different than Wilkinson and Pickett's The Spirit Level (2010), despite that the two are sometimes casually combined in popular thinking. However, in broader context, the context in which Capital is now being read, it is considerably less radical. Here, the laws and the concept of capital become important because they indicate severe limits in terms of what exactly is being explained in Capital. The whole is not counterfeit, but it is misleading and thus dubious in terms of orientation and emphasis.

\section{Calibration economics: what has Piketty really done?}

Recall that Piketty states he is using "the words capital and wealth interchangeably, as if they were perfectly synonymous," (Piketty, 2014: p. 47), and that he defines capital as the "sum total of nonhuman assets that can be owned and exchanged on some market," (Piketty, 2014: p. 46), that is as literally anything that can be designated as having a property right and to which a value can be ascribed (excluding human capital and wage labour). The value of that capital is then measured based on its "market value" established by being "traded on some market," (Piketty, 2014: p. 48). As various critics have noted this definition creates a host of problems (see Galbraith, 2014; Palley, 2014; Varoufakis, 2014). Piketty's concept of capital is essentially a measure of asset wealth based on net present financial value determined in markets. However, capital as a concept, in any insightful sense, is different than a current measure of wealth (for issues see Hodgson, 2014). The two are not synonymous. Capital is the sum of goods that, through a set of social relations, become the means of production, and so capital goods are those that enable economic output. One does not need to be a Marxist to appreciate that this is an important distinction and remains so in terms of Piketty's actual concerns. At the heart of Piketty's 3 laws is the relation between national income and the accumulation of wealth. If one wants to understand the potential for the accumulation of wealth one must account for the way in which national income is generated. One must account for how growth actually occurs, so one must orient on and distinguish capital from all other wealth assets in order to fully explain the historical development of both.

This does not make an interest in the market value of any and all assets irrelevant, but it is important to note that this is quite different than focusing on the actual aspects of an economy that produce the potential for productive wealth. Moreover, maintaining the distinctions and distinguishing between capital and all other forms of wealth assets is also important because this allows one to grasp that differences make a difference, and that the dynamics of wealth include new relations within capitalism that affect what is produced and how (and so "how" affects the shares of income based on wage labour compared to profit shares). This also encompasses different relations to other sources of current wealth. As many have noted a housing bubble is a consequence of quite specific relations within capitalism, it involves the restructuring of an economy around construction and finance, so the form of capital and the structures in which it is used and profits are 
created also change. At the same time the house, though a potential wealth asset, is for the vast majority the place one lives and housing per se cannot simply be dispensed with (it has no return in most contexts even if its value is fluctuating). A house is not capital in the productive sense. However, the existence of housing is also the existence, within quite specific regulatory and rule systems, of a potential for securitisation, resulting then in opportunities for given financial organizations (hedge funds etc) and thereby for the development of speculative wealth assets. These assets, in turn, are significant because of differentials in a broader framework of global finance and its architecture.

What Piketty has actually achieved is an aggregated measure of all wealth assets and how markets treat them. This is important in terms of making some very general claims about the relative wealth of the few compared to the many and in terms of emphasising that overall the proceeds of economies are being captured by the few. But it is in terms of the different aspects of the relation of capital to other forms of assets that the root of any explanation arises. Piketty is overly focused on simply setting up the aggregates of wealth. When viewed in this light it becomes clear that the 3 laws are neither fundamental laws of capitalism nor in some sense deep structures of it. They remain, in the end, no more than highly conditional metrics, despite an initial sense they are the basis of theory. The empirics dominate the 577 pages of Capital. In so far as the 3 laws operate to give sense to the book, they do so by focusing the reader on calibrations. By this I mean the highly generalised or aggregated relative movements of one category in terms of another. ${ }^{\text {xvi }}$

The lasting impression from reading Capital is that despite reference to issues that change the context in which wealth and income become concentrated (war and institutions), and despite Piketty's caveat that "We must be careful not to make a fetish of numbers," (Piketty, 2014: p. 93), the end product does make a fetish of the numbers to the detriment of appropriately developed explanation. It is the calibrations that seem to matter most. This is also made clear if one considers the significance of the metrics.

Consider the role of $r>$ g. Piketty does not just aggregate all forms of wealth assets he conforms their return profiles to a single number. This involves both obfuscation and a slight of hand. There is no reason why the return profiles of all possible assets will move in the same direction at the same time. Some tend to be strongly divergent because of standard investment systems (bonds and equities, gold and almost everything, currencies and commodities combined in hedge and carry trades), some experience singular bubble effects based on historical conjunctures (housing), and these can be common to some economies but rarely universal to all (see Baker, 2014). As such, to aggregate all forms of return into a single figure is highly problematic. It obfuscates regarding the variations in specific return profiles and thus in terms of the actual sources of the return. A focus on a relatively constant and long term return rate gives the impression that the rate itself is the significant issue, caveats notwithstanding, rather than its many and different causes. The metric becomes the actual mechanism rather than a measure. 
It is important to bear in mind that Piketty's aggregate $r$ has to be derived.xvii It does not exist anywhere in the data. This results in a subtle shift in the way the concept is underpinned by Piketty. Piketty defines capital as the market valuation of all assets and so the initial implication is that the return is a combination of market value fluctuations and income streams tied to those assets. In order to fix a relatively constant return to capital Piketty introduces a standard neoclassical approach in Chapter Six. Though he initially criticises the adequacy of the CobbDouglas production function he ultimately chooses to adopt it based on an elasticity of substitution of capital for labour between 1.3 and 1.6 (Piketty, 2014: p. 221). The adoption of this model and substitution means that the expansion of capital in national income is now referenced in a model that is about the return to capital goods, and this is different to the original definition of capital given by Piketty (nor is the model about capital as a social relation, despite being focused on physical product). It does, however, lead to the implication that there is a constant rate of return and to the inference that it can be higher than growth. But this is at the expense of realism. The production function is a standard and highly unrealistic neoclassical model. It assumes that changes are determined by the relative marginal productivity of technology and of labour. Not only is this model deterministic, it requires the assumption that wages are simply a given. As such, in order for the model to be constructable one must put aside any variation in the way technology is really integrated into a productive process and the way in which wages are determined (through bargaining and through the failures to be able to bargain) and unemployment is actually caused. So, as Varoufakis (2014) points out, one must put aside core institutional features of a capitalist economy.

To a non-economist this may not seem that important. But it is. The only reason to adopt a neoclassical production function to underpin the original argument is to give some degree of determinacy to $\beta$ and $r$ (creating periodised regularities). The only reason one would want to do so in this way is to translate the general insights into a form that has some reference point for mainstream economists. ${ }^{\text {xvii }}$ But the point of reference is not clearly compatible with the original definition of capital and the focus on wealth assets, the model itself has no basis in 'fact', even if the data to which it is referred is good data, and so the model undermines Piketty's claim to be concerned with facts. Moreover, the model is simply incompatible with the further claim Piketty quite plausibly makes that institutions matter for who gets what in a capitalist system (particularly the most wealthy). Juxtaposing a neoclassical production function with acknowledgements that institutions - rules, regulations, laws, habits, and cultures - impact on shares of national income does not establish that the two can be integrated. This leads to a final consideration regarding the general coherence of Piketty's approach to explaining wealth and income inequality and to offering a solution.

\section{What Capital is not}

Piketty's laws are not explanations, and when one carefully works through them it is clear they are not really intended to be explanatory. What they are is a set of interconnected mathematical statements that express changes in aggregates of particular metrics. The laws are mechanisms but not in the sense of accounting for something, merely in the sense of producing a machine that processes numbers. 
Moreover, the basis of the laws is compromised by the use of a neoclassical technique (however that is later justified, see Piketty, 2014a; Piketty, 2015), and the overall statement of the laws tends to confuse the reader by conflating capital with all forms of wealth, and capital with the current market valuation of wealth assets. However, though not an explanation, the laws are used to add authority to the central claim that capitalism's normal state is one where wealth does accumulate and concentrate, and where inequality increases.

For Piketty, inequality is the unadulterated normal in capitalism and constraints on the growth of this inequality are an exception, in so far as they are nonnecessary. However, consider what this actually means in terms of the coherence of a theoretical stance. To argue that in the absence of war, or in the absence of specific institutional forms, growing inequality becomes a tendency does not explain the existence of inequality in the absence of war or specific institutional forms. It merely suggests that different conditions apply in the absence of those specific institutions and events. But those different conditions are also the product of institutions within the social relations of capitalism. So, Piketty's way of framing the problem inadvertently makes one set of institutional conditions within capitalism more basic than another. However, this is a problematic implication for many reasons (see also Acemoglu and Robinson, 2015).

First, it conflates prior with more basic. A period of inequality of wealth and income may have occurred historically prior to one that is more egalitarian but that does not make the institutional conditions that enable inequality more fundamental. Second, it tends to conflate duration with primacy, the historical duration of periods of inequality may be longer but again this does not make the institutional conditions that enable inequality more fundamental. Note here that the duration is based initially on few cases. It is the existence of institutional conditions that enabled inequality in those few isolated longer historical cases for which data could exist that lends credence to the sense that the long term underlying state of capitalism involves the tendency for inequality to increase. Third, in order to make the case that one set of institutional conditions are more basic than another - that they are normal and that any alternative is an exception - it is necessary to actually set out those institutions and then to explain how and why they are 'normal'. This requires one to provide historical detail regarding institutions, but also meta-historical and presumably explanatory mechanisms by which capitalism reverts to "deep structures". This requires a historically informed theory of power in capitalist relations, this far more than laws as a metrics exercise would make sense of the data.

However, any effective attempt to explore such theory would quickly come up against the problem that Piketty's core claims trade on the ambiguous status of normal. The inferences drawn from prior and from duration lend credence to the sense that inequality is normal, but normal then further implies that the institutional conditions of that inequality are of trans-historical significance. They are a something to which a system returns. By contrast, periods that place a break on inequality are exceptional, and non-necessary. But this implies that the institutional conditions of inequality are necessary. At the same time they are 
contingent, because history and the data show that a return is not a rerun and alternatives exist. ${ }^{\text {xix }}$

The basic point is that Piketty's argument inadvertently reifies one aspect of a system that exhibits at least two tendencies. The tendency for inequality to rise and the tendency for this to be offset, confronted and challenged. Piketty recognizes the two aspects and is actually intent on providing evidence and argument (albeit with caveats and a degree of hesitation) for the latter, yet the theoretical whole trades on the primary significance of the former. There is a problem of consistency here. Inequality is neither more basic nor more fundamental. It is a contingent outcome of institutional enablement that allows the wealthy to transmit wealth and to capture income, and this is done in particular ways in different places and at different times. All that Piketty really means is that in the absence of effective challenges to the interests of the wealthy, the wealthy will mobilise their wealth as a form of influence, and exercise power to augment their own interests, and this will result in general in institutional arrangements that enable wealth. This is not a profound insight into the deep structures of capitalism it is simply truistic, and a bit simplistic, i.e. more wealth generates more power, and more power generates more wealth, ad infinitum. His laws do not take one beyond this, but the impression is given that they do. On first reading Capital it is easy to be seduced by its relentless focus on the data and the reference to the 3 laws and thereby confuse tracking some issues historically and rendering a theory of history that accounts for those issues. Piketty has achieved the former and not the latter.

What is lacking is a deeper sense that any system and particularly a human system is a process and so is always changing. It exhibits some degree of continuity, it may at times and for periods reproduce similar but not identical states of affairs, and this may occur without the underlying causes of those states of affairs being identical. It may also be profoundly transformed. Put another way, systems are complex, historical, processual and dialectical. There is no sense of this in Piketty's work. Yet this is the major insight one would draw from political economy in terms of how to construct a coherent theory to support and guide the way an empirical argument is pursued. Despite Piketty's stated sympathy for political economy, his work is economics with some discussion of politics, it is not political economy (see Milonakis and Fine 2009; Lawson, 2003).

Here, there are numerous resources one might draw on that might have enhanced the theoretical insight of Capital. Its account of history might have drawn on the work of Hobsbawm and its sense of historical conflict through process might have drawn on Marx, Marxists, regulation theory, systems theory, contemporary global political economy, realist social theory or philosophy and so forth. Piketty does show some interest in Marx, but his interest is essentially technical (e.g. Piketty, 2014: pp. 9-10).xx He shows none, for example, in Polanyi and his concept of a double movement (Polanyi, 1944). A market system may well result in social organization being reconfigured as a set of institutions around that system - a market society; but this is never complete, it always involves provocations to control the adverse consequences, injustices, and relative harms that arise. Neither is more necessary or fundamental to human existence, and each has 
consequences for the other. So, for Polanyi the liberal state is a product and consequence of the emergence of market society. Its potentials are, therefore, not an exception but an internal response. Still, in a certain sense, Piketty's work, taken sympathetically, might be read as a resource intended to enhance the breaks on a market system within a market society, and so be part of that internal response. Still, Piketty seems subject to Polanyi's comment that "Nowhere has liberal philosophy failed so conspicuously as in its understanding of the problem of change," (Polanyi, 1944: p. 41). In his recent International Sociological Association address Michael Burawoy contrasts Polanyi with Piketty and states regarding Piketty's work:

He has no theory of politics, no theory of the state, no theory of social movements, no theory of culture and above all, no theory of capitalism. He has a formula for increasing inequality but the factors behind the variables (rate of return and economic growth) are left unexplained. (Burawoy, 2014: p. 12)

Burawoy's overriding concern is not to advocate Polanyi's work in some unadulterated fashion, but rather to suggest any adequate account of modern capitalism must have an internal sense of both particular causes and general processes. Polanyi, for example, did not foresee a new market fundamentalist countermovement of the type we have witnessed, nor did he clearly distinguish different sources of resistance to it - those arising within the state and those arising within civil society, notably social movements (Burawoy, 2014: p. 22, 268).

One might think that focusing on additional matters of theory in terms of the absence of adequate concepts that account for change etc do not matter a great deal here. Piketty is an economist and not a sociologist. His work is in the end empirical, whilst these matters of theory are of mere academic concern. But this is not so, adequate theory is crucial. Empirical easily becomes empiricism, and empirical work without adequate explanation can lead to an inadequate focus on solutions, since these flow from how one explains the sources of a problem.

It is certainly the case that when read as a book by an economist for economists the focus of theoretical interchange and the language of theory in Capital make sense - discussion of Kuznets, of neoclassical production functions etc. Yet there is a significant difference in terms of acknowledging that Capital is a work of persuasion seemingly targeted at a given audience, and accepting that the work has broader significance as is. Clearly, one wants to avoid the gnomic pursuit of theory. Complexity as academic artifice would do a disservice to the empirical importance of the subject matter of inequality. But Piketty situates his work as "systematic and methodical" and lays claim to be in the pursuit of "scientific" inquiry, albeit imperfectly (see Piketty, 2014: p. 3). One can then easily be lulled into conflating a data exercise, supported by "laws", with the thought that the facts of inequality are now fully accounted for in an appropriate frame of reference. In this sense theory really does matter. It matters because it gives sense to where the explanatory force of facts lie and what this entails. 
As several leading post-Keynesians have argued, Capital lacks specific focus on and then explanation deriving from the particular sectors primarily responsible for the sharp increase in returns to capital and the accumulation of wealth (Galbraith, 2014; Palley, 2014). It also lacks a proper sense of the actual national, regional and global socio-economic systems that have provided the framework in which particular sectors have become significant (Baker, 2014). xxi For example, in the United States, large retail multinational corporations have expanded over the neoliberal period and have done so based on long supply chains and global outsourcing, thus increasing the subordination of production to the power of the retail sector. In the context of neoliberal approaches to employment rights, the relative expansion of employment in this sector has enabled a general rise in the profit share relative to labour share of corporate income (in turn becoming part of relative shares of national income). So, if one were committed to addressing the relative share flowing to capital, an effective policy here would be to improve the specific institutions for collective bargaining and worker's rights in this sector.

The existence of many specific policy approaches highlights that there is a question mark against the logic of argument that leads to the global wealth tax. This does not make a focus on global issues irrelevant - since some aspects of capitalism are part of global system dynamics (e.g. investment flows undertaken by multinational corporations, including financial corporations, since this has many ramifications based on transfer pricing and reporting for corporation tax, local employment conditions, international employment competition that depresses wages, the potential for securitisation etc). However, Piketty's particular argument makes a global wealth tax appear a necessary solution because the focus of Capital is on an aggregated metric. It is ownership of capital as financial assets writ large that is identified as the problem. As such, the implicit line of reasoning is that many sources and types of capital are aggregated in one measure of capital, and this then implies that there is one problem of capital subject to one solution to that problem (see Piketty, 2014: p. 534). But the requirement of a universal and global solution only follows if the problem is actually universal and globally uniform in its sources. It may be possible and in some ways meaningful to provide an aggregate measure of capital that is universal and uniform, but this then makes the possibility of the aggregate measure the reason to orient on a single solution, and this seems to be a fallacy of representation if not of analysis.

This is not to argue a global wealth tax has no appeal, but to reveal that it needs to be carefully conceived (see Patomaki, 2014) and justified. Consider why one would want to orient on a global wealth tax as the main or primary conclusion of a book intended to be the definitive work on wealth, income and inequality. Recall that Piketty states his purpose is "not to plead the case of workers against owners" (Piketty, 2014: p. 40), that "he has no interest in denouncing inequality or capitalism per se" (Piketty, 2014: p. 32), and that the point of his low level global wealth tax is not "to finance the social state but to regulate capitalism. The goal is to stop the indefinite increase of inequality of wealth" (Piketty, 2014: p. 518).

Piketty's global tax is, despite the controversy it provoked from the political right, a conservative policy, and as such a palatable form of radicalism. The tax is 
perfectly compatible with an extremely limited restriction on asset accumulation in order to halt the escalating levels of inequality. As a policy it is also a focus on taking back rather than preventing. A focus on taking back tends to imply redistribution, but this then requires the state to redistribute (and Piketty is not countenancing financing the social state, though he is also supportive of progressive income tax, see Piketty, 2014: pp. 481-484). Moreover, redistribution is a highly limited approach to addressing the problem of inequality. It potentially leaves in place many of the institutions within a market system that give rise to inequality, and so might quickly be overcome through policy capture and reversal because of its own limited ambition. Given that Piketty's main theoretical contribution is to highlight (without exploring) the power of wealth to reproduce its own interests this is surely a major problem for his advocacy of the tax - it would seem to demand a greater and more rigorous transformation of institutions and institutional power in addition to the tax, rather than the introduction of the tax as an alternative to such transformation.

As Robert Wade notes, Capital says little about the power dynamics through which inequality actually arises and how these can be challenged. These are far more controversial practical issues of predistribution, of unionisation, collective rights, and of community empowerment.xxii These would, of course, have made the book far more controversial given its intended audience of economists. But they are not controversial in a broader context. They are, from an alternative perspective, a part of adequate solutions to the real problems stated - including the long term significance of debt-dependent societies and inherently unstable financialised economies (see e.g. Palley 2012; Galbraith 2012). If one considers the social movements that have sprung up in the wake of the global financial crisis, they have been motivated by a deep sense of injustice regarding the very state of society and the role of the economy, and not simply by one visible consequence - growing wealth and privilege. So, whilst Piketty may have been embraced as a voice for the left and for social movements, one should be careful here to consider just how far his work can be an adequate source for those movements. It is in this context that Palley states:

[T]hese things need to be said. Shared values and shared analysis are different. Shared values can create short-term agreements that obscure long-term conflicts inherent in differences of reasoning. Ideas matter and failure to articulate ideas truthfully can have dire consequences. Academic economists have an obligation to state the theoretical issues clearly. Piketty's book is an academic treatise with public policy implications, which means it is right to point out its neoclassical tendencies [...] (Palley, 2014: pp. 145-146)

\section{Conclusion}

Consider what the actual major problems of our time are. They are not income and wealth inequality per se, though these are significant issues. It is poverty and continued environmental harm and human insecurity that are more urgent. It is easy to forget that there is no necessary equivalence between "can we afford the rich?" and "how do we prevent the poor?". If Piketty's work leads to a global wealth 
tax that slows down and then halts inequality along conservative lines this will do little substantively to address the structural causes of difference that give rise to poverty. Again, the work is not irrelevant - even the OECD (2014) recognizes that developing countries tend to fair better where inequality is lower. Inequality does matter. As recently claimed by Oxfam (and the claim uses the World Top Incomes Database) the 85 richest people in the world now own wealth equivalent to the bottom 3.5 billion (Oxfam, 2014). But using the data on which Capital is built is different than suggesting Capital is an appropriate guide for solutions.

A break on wealth accumulation is not a different way of constituting capitalism. Concomitantly, we are already in need of a different way of constituting capitalism if we are to address the basic environmental disaster we seem to be blithely heading towards. It seems curious that Piketty can make forecasts across a whole century regarding growth and make only passing reference to the need to solve the carbon problem and no mention as to whether growth ought to be an aim at all (Piketty, 2014: p. 95).

\section{References}

Acemoglu, D. and Robinson, J. (2015) 'The rise and decline of general laws of capitalism', Journal of Economic Perspectives 29(1): 3-28

Baker, D. (2014) 'Capital in the Twenty-First Century: are we doomed without a wealth tax?' pp. 270-278 in Fullbrook and Morgan, editors (2014)

Burawoy, M. (2015) 'Facing an unequal world', Current Sociology 63(1): 5-34

Colledge, B., Morgan, J. and Tench, R. (2014) 'The concept(s) of trust in late modernity, the relevance of realist social theory' Journal for the Theory of Social Behaviour 44(4): 481-503

Dorling, D. (2014) Inequality and the 1\% London: Verso

The Economist (2014a) 'All men are created unequal', The Economist, January $4^{\text {th }}$

The Economist (2014b) 'A modern Marx', The Economist, May $3^{\text {rd }}$

Eichengreen, B. (2015) Hall of Mirrors Oxford: Oxford University Press

Erlanger, S. (2014) 'Taking on Adam Smith (and Karl Marx)', The New York Times, April 19th

Fullbrook, E. and Morgan, J. editors (2014) Piketty's Capital in the Twenty-First Century London: College Publications

Galbraith, J. (2014) 'Unpacking the first fundamental law' pp. 225-30 in Fullbrook and Morgan, editors (2014)

Galbraith, J. (2012) Inequality and Instability Oxford: Oxford University Press

Giles, C. (2014) 'Thomas Piketty's exhaustive inequality data turns out to be flawed', Financial Times, May $23^{\text {rd }}$

Giovannoni, 0. (2014) 'What do we know about the labor share and the profit share? Part III', Levy Institute Working Papers: Number 805

Hodgson, G. (2014) 'What is capital? Economists and sociologists have changed its meaning: should it be changed back?' Cambridge Journal of Economics 38(5): 1063-1086

Kaplan, S. and Rauh, J. (2013) 'It's the market: the broad-based rise in the return to top-talent', Journal of Economic Perspectives 27(3): 35-56

Krugman, P. (2014a) 'Wealth over work', The New York Times, March 23 ${ }^{\text {rd }}$ 
Krugman, P. (2014b) 'America's Taxation Tradition', The New York Times, March $27^{\text {th }}$

Lawson, T. (2003) Reorienting Economics London: Routledge

Lazonick, W. (2013) 'The financialization of the US corporation: what has been lost and how it can be regained', Seattle University Law Review 36(2): 857909

Mankiw, G. (2013) 'Defending the one percent', Journal of Economic Perspectives 27(3): 21-34

Mankiw, G. (2015) 'r>g So what?' American Economic Review 105(5): 43-47

Milanovic, B. (2014) 'My view on Piketty's critique by the FT', Mike Norman Economics May 25 th http://brankomi.wix.com/inequality

Milonakis, D. and Fine, B. (2009) From political economy to economics. London: Routledge.

Morgan, J and Sheehan, B. (2015) 'Has reform of global finance been misconceived? Policy documents, and the Volcker Rule' Globalizations 12(5): 695-709

OECD (2014) 'Focus on inequality and growth', Paris: OECD available from: http://www.oecd.org/els/soc/Focus-Inequality-and-Growth-2014.pdf

Oxfam (2014) Working for the few: Political capture and economic inequality Oxfam

Palley, T. (2014) 'The accidental controversialist: Deeper reflections on Thomas Piketty's Capital', Real World Economics Review 67: 143-146

Palley, T. (2012) From Financial Crisis to Stagnation Cambridge: Cambridge University Press

Patomaki, H. (2014) 'Piketty's global tax on capital: A useful utopia or a realistic alternative to a global disaster?' pp. 85-94 in Fullbrook and Morgan editors (2014)

Piketty, T. (2014) Capital in the Twenty-First Century London: Belknap Press

Piketty, T. (2014a) 'Interview with Thomas Piketty: Piketty Responds to Criticisms from the Left', by Antoine Dolcerocca and Gokhan Terzioglu Potemkin Review 1(1): no pagination; online at: http://potemkinreview.com/pikettyinterview/

Piketty, T. (2015) 'Putting distribution back at the centre of economics: Reflections on Capital in the Twenty-First Century', Journal of Economic Perspectives 29(1): 67-88

Polanyi, K. (1944) Origins of Our Time: The Great Transformation London: Victor Gollancz

Sayer, A. (2014) Why We Can't Afford The Rich London: Policy Press

Shuchman, D. (2014) 'Thomas Piketty Revives Marx for the 21st Century', Wall Street Journal, April $21^{\text {st }}$

Smith, D. (2014) 'Why has this Frenchman got the world at his feet?' The Sunday Times April 27th

Solow, R. (2014) 'Thomas Piketty is right: Everything you need to know about Capital in the Twenty-First Century' New Republic April 22nd

Varoufakis, Y. (2014) 'Egalitarianism's latest foe: a critical review of Thomas Piketty's Capital in the Twenty-First Century', pp. 35-62 in Fullbrook and Morgan, editors (2014) 
Wade, R. (2014) 'The Piketty Phenomenon and the future of inequality', pp. 1034 in Fullbrook and Morgan, editors (2014)

Wilkinson, R and Pickett, K (2010) The Spirit Level: Why Equality if Better for Everyone London: Penguin [with new postscript]

Wolf, M. (2014) 'Capital in the Twenty First Century by Thomas Piketty', Financial Times, April 15th

\begin{abstract}
i For prior context see Citigroup's plutonomy/plutocracy 2005-6 and Lazonick (2013).
ii For examples of lavish praise from prominent economists and commentators see Krugman 2014a, 2014b; Wolf, 2014; Solow, 2014; Erlanger, 2014. The Economist provided an initially neutral review, January 2014a, but then became more hostile May 2014b, where Piketty becomes a radical socialist/Marxist, an accusation repeated in the Wall St Journal, where Shuchman (2014) refers to Capital as a 'bizarre ideological screed'. The Financial Times also began a critique of Piketty's data in May (Giles, 2014) but this came to little following a detailed response by Milanovic (2014) and also Piketty.

iii "It is by no means certain that inequalities of wealth are actually increasing at the global level: as the poorer countries catch up with the richer ones, catch-up effects may for the moment outweigh the forces of divergence," (Piketty, 2014: p. 438)

iv There is a broader database that tracks estimated world output growth rates and returns to capital across two millennia (Piketty, 2014: pp. 73, 354, 356-7)

$v$ Though Piketty makes it clear that the decline in income share is not a result of significant growth in the relative labour income of the rest of society compared to the top $10 \%$ even during the period of exception. This is one reason why there is no simple and enduring Kuznet effect to be found in the data.

vi One can get a continual update from the World Top Incomes Database. This remains an invaluable publically accessible source made freely available for dissemination by the contributors, including Thomas Piketty. No criticism of Capital militates against this. For the material stated so far see:
\end{abstract}

Top income shares. United States. 1913-2012

Sources: The World Top Incomes Database. http://topincomes.g-mond.parisschoolofeconomics.eu/ Piketty \& Saez (2007)

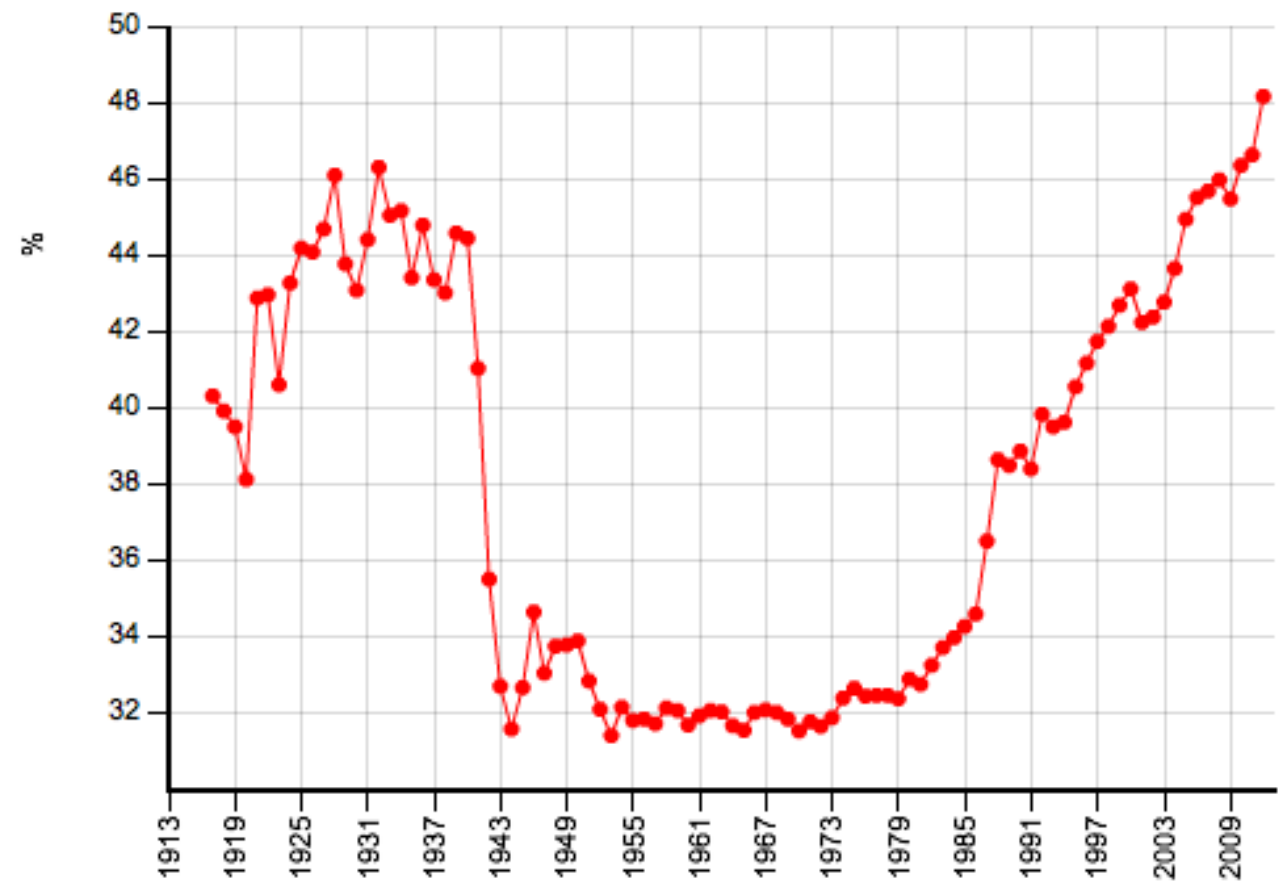

$\checkmark$ Top $10 \%$ income share 
Top income shares. United States. 1913-2012

Sources: The World Top Incomes Database. http://topincomes.g-mond.parisschoolofeconomics.eu/ Piketty \& Saez (2007)

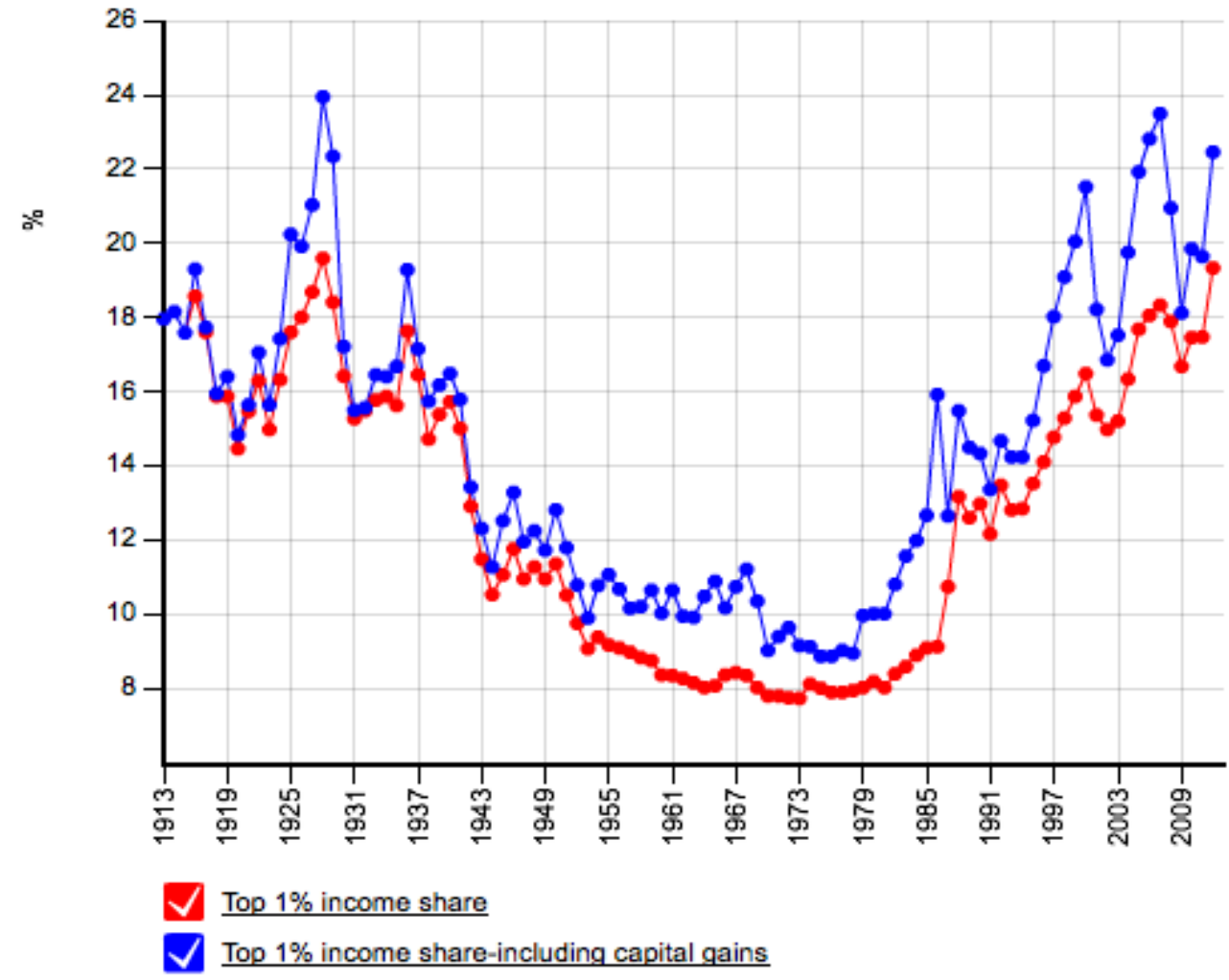

Top income shares. United Kingdom. 1908-2011

Sources: The World Top Incomes Database. http://topincomes.g-mond.parisschoolofeconomics.eu/ Atkinson (2007)

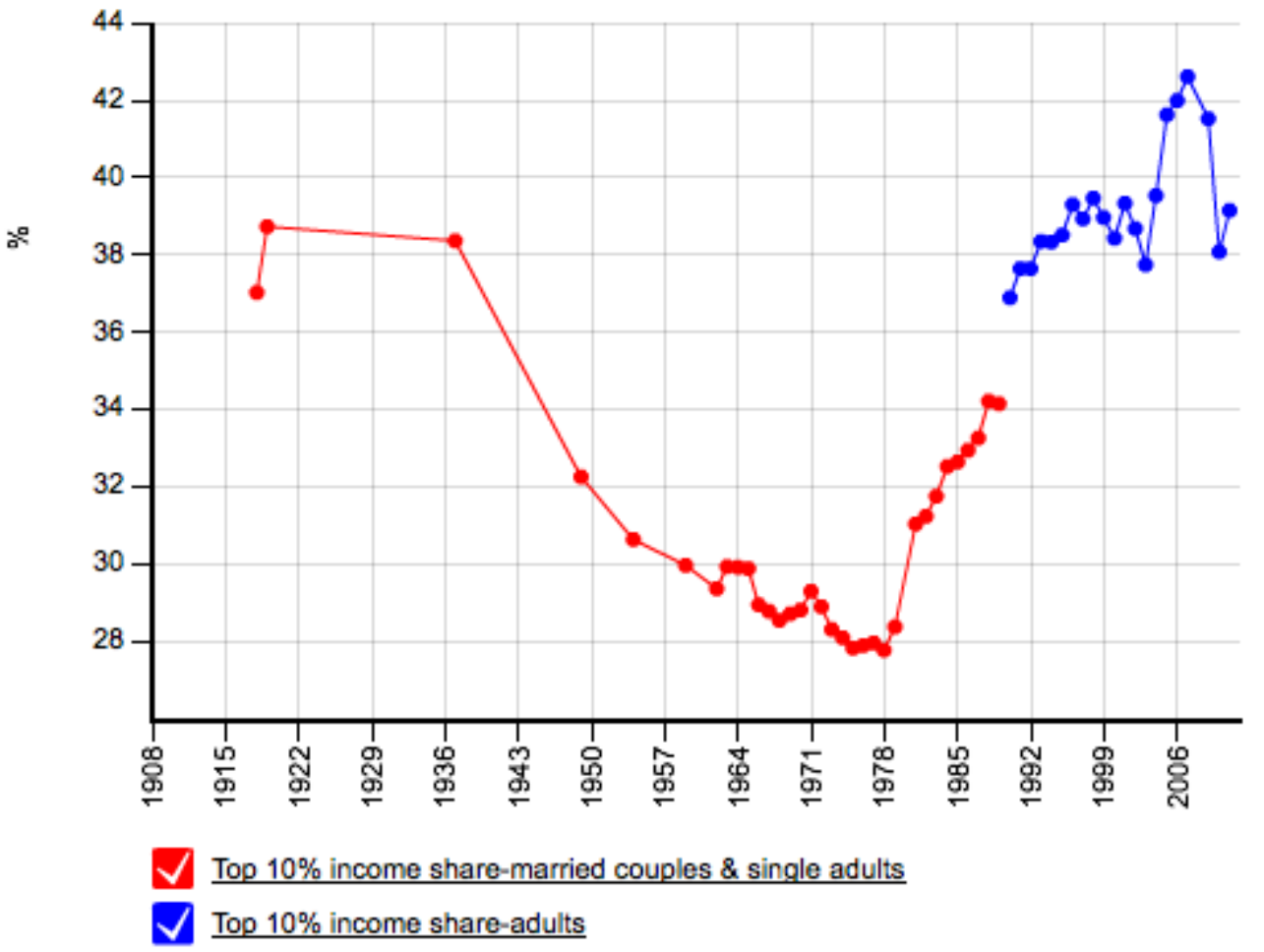


Top income shares. United Kingdom. 1908-2011

Sources: The World Top Incomes Database. http://topincomes.g-mond.parisschoolofeconomics.eu/ Atkinson (2007)

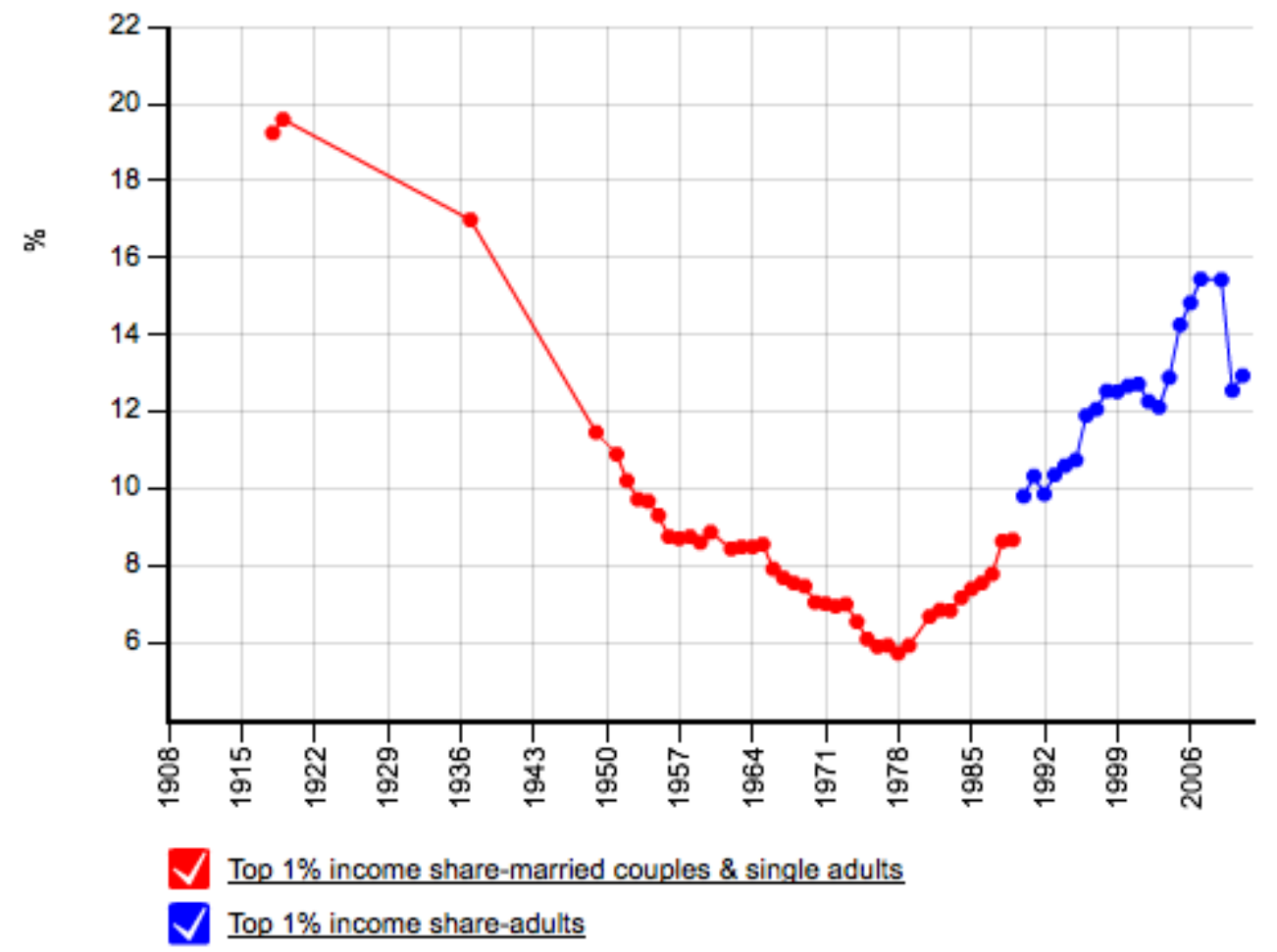

vii The book has many useful summaries. For example: "Two points need to be clarified at once. First we find this regularity in all countries in all periods for which data are available, without exception, and the magnitude of the phenomenon is always quite striking. To give a preliminary idea of the order of magnitude in question, the upper 10 per cent of the labour income distribution generally receives 25-30 per cent of total labour income, whereas the top 10 per cent of the capital income distribution always owns more than 50 per cent of all wealth." (Piketty, 2014: p. 244)

viii I have omitted reference in the following to net figures and relative populations in order to keep the explanation simple.

ix Even the copyeditor seems to have become exhausted by the length and gravity of the work: "all needs should by paid for through taxation" (Piketty, 2014: p. 482).

x However, see Piketty, 2014: p. 574

${ }^{x i}$ And where the recognized "unequal returns on capital are a force for divergence that significantly amplifies and aggravates the effects of the inequality r>g." (Piketty, 2014: p. 431)

xii Piketty notes that the long term cumulative effects of these growth rates are more significant than the public realise, which is one reason why people think growth rates are higher (in addition to the variation between states rather than as a world output possibility frontier). An annual rate of $1.5 \%$ over thirty years accumulates to more than $50 \%$ growth in national income or output. (Piketty, 2014: p. 95)

xiii "In the standard economic model, based on the existence of a "perfect" market for capital (in which each owner of capital receives a return equal to the highest marginal productivity available in the economy, and everyone can borrow as much as he or she wants at that rate), the reason why the return on capital, $r$, is systematically and necessarily higher than the growth rate $g$ is the following. If $r$ were less than $g$, economic agents, realizing that their future income (and that of their descendents) will rise faster than the rate at which they can borrow, will feel infinitely wealthy and will therefore wish to borrow without limit in order to consume immediately (until $r$ rises above $\mathrm{g}$ ). In this extreme form, the mechanism is not entirely plausible, but it shows that $r>g$ is true in the most standard of economic models and is even more likely to be true as capital markets become more efficient." (Piketty, 2014: p. 360) The implicit argument is that standard 
models are not fully correct but they do support the existence of $r>g$ so they are therefore relevant as a point of departure.

xiv Note, this is different than Piketty's support for a progressive income tax

xv There are numerous arguments one might make - though most miss the point in terms of context and possibilities. For example, the rich are the main single group within most advanced capitalist countries tax base, despite issues such as tax evasion. As of 2013, in the UK the top $1 \%$ accounted for $30 \%$ of income tax revenues and the top $10 \%$ for $59 \%$. This compares with $11 \%$ and $35 \%$ in 1979. So they actually seem to contribute more than was the case in a period of higher taxation (Smith, 2014).

xvi Calibration is used slightly differently in econometrics - there it usually refers to adjusting variables to create outcomes either without data or in ways that condition any subsequent data. Piketty's laws are not quite this - see subsequent sections.

xvii Here, Galbraith (2014) provides a useful deconstruction of the maths: since $\alpha$ is the share of profit in total income, which can be written as $\mathrm{P}$ for profit and $\mathrm{Y}$ for income or $\mathrm{P} / \mathrm{Y}$; and $\alpha$ is calculated as $\alpha=r \times \beta$; where $\beta$ is the capital or $\mathrm{k}$ ratio of income $\mathrm{Y}$, then one can write $\mathrm{P} / \mathrm{Y}=r \mathrm{X}$ $\mathrm{K} / \mathrm{Y}$ and rearrange this as $\mathrm{r}=\mathrm{P} / \mathrm{Y} \div \mathrm{K} / \mathrm{Y}$; if one then cancels $\mathrm{Y}$ then one is left with $\mathrm{r}=\mathrm{P} / \mathrm{K}$. $r$ is then revealed to also be highly contingent because, if one factors in tax on profits and also some consumption from profits then one can easily demonstrate $\mathrm{r}$ at $2.5 \%$ rather than $5 \%$.

Varoufakis (2014) highlights a whole set of associated problems of assumptions in the laws. For example, the second law requires net savings to feed fully into aggregate wealth; it may be that savings rates are falling but the value of capital rising because of market effects (including for example, intra-financial multiplication).

xviii Piketty has subsequently stated that he did not intend his discussion of the neoclassical production function and its specific substitution rate to be read in the way it has been. The point was to address a neoclassical audience in terms they would understand and to show that even if one accepted their highly unrealistic model then problems of inequality still arise over time. (Piketty 2014a). However, if this was his only intention then he failed to convey that effectively in Capital.

xix The thrust of Piketty's argument is also that capitalism has no inherent mechanisms that prevent concentrations of wealth and income. But what makes something inherent in a system like capitalism? Why are mechanisms of concentration inherent whilst those that prevent this are not? Capitalism may have basic capacities and defining social relations but the actual distribution within this is contingent on the institutions that arise. This is fundamental to Sraffa and Robinson's position in the Cambridge Controversy that Piketty also curiously misrepresents (see Sraffa's Production of Commodities by Commodities).

xx Piketty's use of Marx fails to read through the technical issues to see the underlying purpose in a constructive way. It is easy for an unwary reader to approach Piketty's concept of capital as one that is basically Marxist and refers to a class. Recall: "Very soon, however, capital began to reconstitute itself. The growth of capital's share accelerated with the victories of Margaret Thatcher in England in 1979 and Ronald Reagan in the United States in 1980, marking the beginning of a conservative revolution [...] By 2010, and despite the crisis that began in 2007-2008 capital was prospering as it had not done so since 1913." (Piketty, 2014: p. 42)

xxi Even the possible issue of a transnational capitalist class is not pursued despite the acknowledgement that "financial globalization has made it more difficult to measure wealth and its distribution in a national framework: inequality of wealth in the twenty first century will have to be gauged more and more at the global level." (Piketty, 2014: p. 346) It seems curious that a data constraint is used to then ignore a problem of explanatory relevance.

xxii Piketty does not address the way MNCs have effective monopoly power, nor how this translates into systems of political patronage and policy capture, especially in democracies where political campaigning and party activity is not publically funded and private interests are not curtailed; he says nothing about issues of privatisation versus nationalisation for natural monopolies and for welfare goods; nor does he address the living wage, the minimum wage, citizen's income or the way tax systems privilege rentier activity in general (capital gains tax, the tax status of debt etc); or how the whole architecture of regional institutions is currently configured to punish any given state that attempts to place its people before its existing financial commitments - anti-austerity policies are not wrong per se - they are simply denied the scope to succeed on their own terms (as Greece is currently finding in its negotiations with the ECB); nor does Piketty address what it might mean to definancialise an economy. 